\title{
A PETROLOGIC EVALUATION OF THE LAYOU IGNIMBRITE AND MORNE TROIS PITON LAVA DOME: HOW DO CHANGES IN PRE-ERUPTIVE CONDITIONS AFFECT ERUPTIVE BEHAVIOR?
}

JUSTIN CASAUS, Sonoma State University

Research Advisor: Laura Waters

\section{INTRODUCTION}

One of the most active volcanic centers in the Central Lesser Antilles is the island of Dominica, which features nine active volcanic centers, periodic earthquake swarms and seismic activity, as well as phreatic eruptions (non-magmatic explosive steam eruption) (Lindsay et al., 2005). The frequency with which Dominica features voluminous eruptions of pyroclastic andesite flows presents an immediate hazard for communities on Dominica and underscores the importance of investigating the pre-eruptive storage conditions experienced by previous eruptions to determine whether or not mechanisms that can induce eruption can be identified. Here, we evaluate the Layou Ignimbrite and the Morne Trois Piton dome to discern any variations in their pre-eruptive intensive variables, which may explain the shift in eruptive behavior.

\section{GEOLOGIC SETTING}

Dominica is located in the Central Lesser Antilles island arc, located in the Eastern Caribbean Ocean, where the North and South American plates are subducting beneath the Caribbean plate at an average angle of $70^{\circ}$ and a rate of $1.9 \mathrm{~cm} / \mathrm{yr}$ (DeMets et al., 2000). Dominican volcanics range in composition from mafic (basalt) to intermediate (andesite) (48-63 wt. $\% \mathrm{SiO}_{2}$ ); dacites (63-70 wt. \% $\mathrm{SiO}_{2}$ ) are occasionally observed (Smith et al., 2013). Notably, the more silicic lavas typically explosively erupt as ignimbrites or effusively erupt as domes. The Layou Ignimbrite is the most evolved composition on the island. Mapping by Smith et al. (2013) reveals that its likely source is approximately the location of the present day edifice Morne Trois Piton, a crystal rich lava dome. The Layou ignimbrite is dramatically exposed along the Layou River, where incision has exposed a $\sim 4 \mathrm{~m}$ section of interbedded pumice clasts and ash. Though Dominica is highly vegetated, the Morne Trois Piton dome is actively quarried, which provides excellent exposures of fresh rock in the interior of the dome.

\section{METHODS}

Rock samples of the Morne Trois Piton lava dome were collected from a quarry located on the northern side of the dome. Samples were selected to accurately reflect the observed heterogeneity in the outcrop. We observed light- and dark-grey banding of various crystal-rich andesite, as well as numerous inclusions. Layou ignimbrite samples and most data were obtained by Frey and research students over three field seasons. Morne Trois Piton rock samples were cut and processed into thin sections for microbeam analyses at Union College, Schenectady New York. Samples of the Light Grey and Dark Grey portions of the Morne Trois Piton rock samples were first crushed to approximately $1 \mathrm{~cm}$ or smaller using a RockLabs laboratory hydraulic crusher/breaker. The crushed samples were then reduced to powder using the RockLabs aluminum oxide grinding vessel. For whole rock composition analysis by ICP-OES, the powdered samples were sent to Acme Labs. The remaining portion of the powdered samples were first dissolved using hydrofluoric acid, 
Table 1: Whole Rock Geochemistry and Modal Abundances

\begin{tabular}{|c|c|c|c|c|c|c|c|c|c|c|}
\hline \multirow{3}{*}{$\begin{array}{l}\text { Descriptor } \\
\text { Sample }\end{array}$} & \multicolumn{5}{|c|}{ Ignimbrite } & \multicolumn{5}{|c|}{ Dome } \\
\hline & $\begin{array}{l}\text { Pumice } \\
\text { Clast } 1\end{array}$ & $\begin{array}{l}\text { Pumice } \\
\text { Clast } 2\end{array}$ & $\begin{array}{l}\text { Pumice } \\
\text { Clast } 3\end{array}$ & $\begin{array}{l}\text { Pumice } \\
\text { Clast } 4\end{array}$ & $\begin{array}{l}\text { Average } \\
\text { Pumice }\end{array}$ & $\begin{array}{l}\text { Dark } \\
\text { Grey }\end{array}$ & $\begin{array}{l}\text { Dark } \\
\text { Grey }\end{array}$ & $\begin{array}{l}\text { Dark } \\
\text { Grey }\end{array}$ & $\begin{array}{c}\text { Average } \\
\text { Dark }\end{array}$ & Light Grey \\
\hline & LV-1 & LV-2 & LV-3A & LV-4 & & MTP-2D-A & MTP-Q-DG & MTP-2A-A & Grey & MTP-Q-LG \\
\hline $\mathrm{SiO}_{2}$ & 64.49 & 65.74 & 64.18 & 65.67 & 65.02 & 62.33 & 62.04 & 62.49 & 62.29 & 63.17 \\
\hline $\mathrm{TiO}_{2}$ & 0.44 & 0.39 & 0.45 & 0.38 & 0.41 & 0.5 & 0.52 & 0.48 & 0.5 & 0.47 \\
\hline $\mathrm{Al}_{2} \mathrm{O}_{3}$ & 16.59 & 16.45 & 16.43 & 16.42 & 16.47 & 16.9 & 17.2 & 17.11 & 17.07 & 17.03 \\
\hline $\mathrm{FeO}^{\mathrm{T}}$ & 5.2 & 4.67 & 5.35 & 4.68 & 4.97 & 5.9 & 5.92 & 5.69 & 5.84 & 5.34 \\
\hline $\mathrm{MnO}$ & 0.14 & 0.13 & 0.15 & 0.14 & 0.14 & 0.15 & 0.15 & 0.14 & 0.15 & 0.14 \\
\hline $\mathrm{MgO}$ & 2.09 & 1.71 & 2.18 & 1.72 & 1.92 & 2.48 & 2.53 & 2.33 & 2.45 & 2.23 \\
\hline $\mathrm{CaO}$ & 5.58 & 5.3 & 5.7 & 5.39 & 5.49 & 6.23 & 6.34 & 6.22 & 6.27 & 6.14 \\
\hline $\mathrm{Na}_{2} \mathrm{O}$ & 3.22 & 3.34 & 3.26 & 3.37 & 3.3 & 3.27 & 3.35 & 3.31 & 3.31 & 3.35 \\
\hline $\mathrm{K}_{2} \mathrm{O}$ & 1.56 & 1.63 & 1.58 & 1.6 & 1.59 & 1.46 & 1.4 & 1.48 & 1.45 & 1.51 \\
\hline $\mathrm{P}_{2} \mathrm{O}_{5}$ & 0.1 & 0.12 & 0.12 & 0.11 & 0.11 & 0.12 & 0.1 & 0.11 & 0.11 & 0.1 \\
\hline Total & 99.42 & 99.5 & 99.4 & 99.48 & 99.45 & 99.34 & 99.94 & 99.37 & 99.55 & 99.93 \\
\hline \multicolumn{11}{|l|}{$\begin{array}{l}\text { Modal } \\
\text { Abundances }\end{array}$} \\
\hline Plag & 10.8 & 11.2 & 13.8 & 20.4 & 14.1 & 34.6 & 27.4 & 35.3 & 32.4 & 34.6 \\
\hline $\mathrm{Cpx}$ & 2.9 & 0.6 & 1.8 & 1.4 & 1.7 & 3.3 & 2.5 & 3.9 & 3.2 & 2.1 \\
\hline Opx & 2.1 & 1 & 1.8 & 1.3 & 1.5 & 2.9 & 6.6 & 2.3 & 3.9 & 5.7 \\
\hline $\mathrm{Ox}$ & 1.7 & 0.9 & 1.6 & 1.4 & 1.4 & 3.3 & 2.9 & 1.6 & 2.6 & 3.6 \\
\hline $\mathrm{Hbl}$ & 2.1 & 2 & 2.2 & 2.2 & 2.2 & 2.3 & 0.7 & 0.6 & 1.2 & 0.8 \\
\hline Qtz & 0 & 0.4 & 0.1 & 0.2 & 0.2 & 1.4 & 0 & 0.4 & 0.6 & 0 \\
\hline gdms & 69.6 & 62.5 & 59.6 & 60.1 & 63 & 48.4 & 52.6 & 45.2 & 48.7 & 44.6 \\
\hline ves & 10.8 & 21.4 & 17.1 & 12.9 & 15.5 & 3.9 & 7.3 & 10.7 & 7.3 & 8.6 \\
\hline Total & 100 & 100 & 97.9 & 99.9 & 99.5 & 100 & 100 & 100 & 100 & 100 \\
\hline
\end{tabular}

then nitric acid. The dissolved samples were then analyzed for trace elements using a PerkinElmer/ Sciex Elan 6100 DRC inductively coupled plasma mass spectrometer on site at Union College of Schenectady, New York. Point count analyses consisting of 1000 points were performed using PETROG's stepping stage and PetrogLite on site at Union College. Point counts of the Layou Ignimbrite samples were additionally compared to previous students counts to ensure accuracy.

Plagioclase, ilmenite, and magnetite were analyzed in each sample using a standard carbon coating of thin sections in the Zeiss EVO MA15 scanning electron microscope (SEM) located at Union College of Schenectady, New York. The Zeiss SEM was utilized for the back scatter electron (BSE) imaging and quantitative analyses with the Bruker electron dispersive spectrometer (EDS). Spectra analyses were collected over a period of 30 seconds. The EDS analyses were conducted following a calibration method, where the initial beam intensity is obtained by collecting the energy emitted by a copper plate, and then EDS spectra are collected for natural mineral standards in the Union College collection. Plagioclase, ilmenite, and magnetite were reanalyzed in select samples using the Cameca SX-100 Electron Microprobe using wavelength dispersive spectrometry (WDS) at the Univer- sity of California Davis. For analyses conducted with the electron microprobe, a beam intensity of $15 \mathrm{KeV}$ was used along with an intensity of $20 \mu \mathrm{m}$ and $10 \mu \mathrm{m}$ for oxides and plagioclase, respectively.

\section{RESULTS}

\section{Sample Petrography and Whole Rock Geochemistry}

Point counts from three different thin sections reveal that the Layou Ignimbrite contains $22 \%$ crystals on average (including vesicles) and is multiply saturated in seven phenocrystic phases (plagioclase + hornblende + clinopyroxene +orthopyroxene + ilmenite + magnetite + quartz) as shown in Table 1. The pumice samples have an average vesicularity of $\sim 15 \%$.The Morne Trois Piton dome is intermediate in composition and contains approximately $45 \%$ crystals and a phase assemblage identical to the Layou Ignimbrite with a few notable distinctions. The Morne Trois Piton samples have more plagioclase, hornblende crystals in the dome are significantly reacted, quartz in the dome samples occurs in a greater abundance and size, and there are notably fewer vesicles- consistent with an effusive eruption. Analyses of pumices from the Layou Ignimbrite reveal that there is little heterogeneity between clasts, and that the Layou Ignimbrite is dacitic and one of the most evolved rocks erupted on 
Table 2: Ilmenite and Magnetite Compositions

\begin{tabular}{|c|c|c|c|c|c|c|}
\hline & \multicolumn{4}{|c|}{ Dome } & \multirow{2}{*}{\multicolumn{2}{|c|}{ Ignimbrite }} \\
\hline & \multicolumn{3}{|c|}{ Dark Grey } & \multirow{2}{*}{$\begin{array}{l}\text { Light Grey } \\
\text { MTP-Q }\end{array}$} & & \\
\hline Sample & MTP-2D-A & MTP-2A & MTP-Q & & LV1 & LV2 \\
\hline Phase & IL & IL & IL & $\mathrm{IL}$ & IL & $\mathrm{IL}$ \\
\hline No. of Analyses & 10 & 10 & 9 & 10 & 15 & 10 \\
\hline $\mathrm{SiO} 2$ & 0.03 & 0.02 & 0.11 & 0.01 & 0.08 & 0.03 \\
\hline $\mathrm{TiO} 2$ & 46.43 & 46.09 & 45.29 & 45.53 & 48.42 & 46.54 \\
\hline $\mathrm{A} 12 \mathrm{O} 3$ & 0.15 & 0.13 & 0.14 & 0.12 & 0.26 & 0.14 \\
\hline $\mathrm{Fe} 2 \mathrm{O} 3$ & 13.38 & 14.32 & 15.37 & 15.15 & 11.18 & 12.69 \\
\hline $\mathrm{V} 2 \mathrm{O} 3$ & 0.15 & 0.13 & 0.15 & 0.11 & 0.00 & 0.12 \\
\hline $\mathrm{Cr} 2 \mathrm{O} 3$ & 0.01 & 0.01 & 0.00 & 0.01 & 0.06 & 0.01 \\
\hline $\mathrm{FeO}$ & 36.80 & 36.43 & 35.72 & 35.98 & 39.75 & 37.32 \\
\hline $\mathrm{MnO}$ & 0.92 & 0.90 & 0.94 & 1.04 & 0.42 & 0.85 \\
\hline $\mathrm{MgO}$ & 1.66 & 1.79 & 1.75 & 1.71 & 1.31 & 1.54 \\
\hline $\mathrm{CaO}$ & 0.05 & 0.03 & 0.04 & 0.03 & 0.03 & 0.03 \\
\hline Total & 99.57 & 99.86 & 99.51 & 99.70 & 101.52 & 99.27 \\
\hline$X_{\text {Ilmenite }}$ & 79.12 & 77.86 & 76.84 & 77.00 & 83.89 & 80.32 \\
\hline $\pm 1 \sigma \mathrm{X}_{\text {Ilmenite }}$ & 3.42 & 1.04 & 1.45 & 1.94 & 1.21 & 0.46 \\
\hline Phase & MT & MT & MT & MT & MT & MT \\
\hline No. of Analyses & 11 & 12 & 10 & 10 & 12 & 11.00 \\
\hline $\mathrm{SiO} 2$ & 0.09 & 0.08 & 0.07 & 0.08 & 0.13 & 0.08 \\
\hline $\mathrm{TiO} 2$ & 9.89 & 10.64 & 9.66 & 9.40 & 9.64 & 9.61 \\
\hline $\mathrm{Al} 2 \mathrm{O} 3$ & 1.44 & 1.49 & 1.41 & 1.37 & 1.98 & 1.86 \\
\hline $\mathrm{Fe} 2 \mathrm{O} 3$ & 47.58 & 46.47 & 48.13 & 48.74 & 48.00 & 47.53 \\
\hline $\mathrm{V} 2 \mathrm{O} 3$ & 0.66 & 0.66 & 0.62 & 0.54 & 0.35 & 0.58 \\
\hline $\mathrm{Cr} 2 \mathrm{O} 3$ & 0.03 & 0.03 & 0.02 & 0.03 & 0.06 & 0.03 \\
\hline $\mathrm{FeO}$ & 38.66 & 39.21 & 38.19 & 37.87 & 39.67 & 38.52 \\
\hline $\mathrm{MnO}$ & 0.56 & 0.62 & 0.57 & 0.65 & 0.00 & 0.52 \\
\hline $\mathrm{MgO}$ & 0.79 & 0.94 & 0.93 & 0.86 & 0.57 & 0.74 \\
\hline $\mathrm{CaO}$ & 0.02 & 0.02 & 0.01 & 0.04 & 0.03 & 0.02 \\
\hline Total & 99.73 & 100.17 & 99.61 & 99.58 & 100.43 & 99.50 \\
\hline $\mathrm{X}_{\text {Ulvospinel }}$ & 28.03 & 29.98 & 27.39 & 26.69 & 27.12 & 27.26 \\
\hline $\pm 1 \sigma \mathrm{X}_{\text {Ulvospinel }}$ & 2.60 & 1.74 & 1.75 & 1.43 & 0.61 & 0.37 \\
\hline $\mathrm{T}\left({ }^{\circ} \mathrm{C}\right)$ & $798 \pm 39$ & $834 \pm 15$ & $821 \pm 27$ & $812 \pm 21$ & $769 \pm 12$ & $793 \pm 7$ \\
\hline$\triangle \mathrm{NNO}$ & $0.10 \pm 0.2$ & $0.23 \pm 0.1$ & $0.38 \pm 0.17$ & $0.4 \pm 0.1$ & $-0.1 \pm 0.1$ & $0.1 \pm 0.1$ \\
\hline
\end{tabular}

Temperature and $\Delta \mathrm{NNO}$ are average $( \pm 1 \sigma)$ from all possible pairings of ilmenite and titanomagnetite

analyses and the model of Ghiorso and Evans (2008).

the island. Analyses of the Morne Trois Piton dome samples show that the dome is andesitic. Additionally, analyses of specific samples on a color basis reveal trivial compositional differences. The light grey samples are slightly more evolved than the dark grey samples, as they have lower concentrations of $\mathrm{CaO}$ and $\mathrm{FeO}$ (though the difference is not remarkable).

\section{Oxide Compositions}

Ilmenite and magnetite crystals span a relatively narrow range in composition (Table 2). All possible pairs of ilmenite and magnetite within the Layou Ignimbrite and Morne Trois Piton samples were tested using the Bacon \& Hirschmann (1988) assessment of equilibrium. The oxide pairs plotted from the Layou Ignimbrite fall well within the defined upper and lower limits, whereas oxide pairs from Morne Trois Piton samples spanned a range but broadly overlapped with the equilibrium criteria.

\section{Plagioclase Compositions}

Plagioclase compositions (corresponding to 127 analyses of two samples) in the Layou Ignimbrite (Fig. 1a) span a continuous range from $\mathrm{An}_{88}$ to $\mathrm{An}_{42}$. Both samples have calcic plagioclase compositions that gradually increase in abundance to form a distinct peak at $\sim \mathrm{An}_{54}$ then rapidly decrease in abundance to more sodic compositions $\mathrm{An}_{44}$. Plagioclase in the Morne Trois Piton samples form a slightly more complex pattern in compositions; compositions (shown as a histogram in Fig 1b) occur in three models, one occurring at $\sim \mathrm{An}_{90}$, another at $\sim \mathrm{An}_{72}$, and a third occurring at $\sim \mathrm{An}_{54}$. Upon close inspection the majority of the plagioclase compositions that form the peak at $\mathrm{An}_{90}$ come from a single large calcic plagioclase in a dark grey sample from the Morne Trois Piton dome. The remaining two peaks come from core-to-rim plagioclase analyses of relatively euhedral crystals, which produce this bimodal pattern. The Morne Trois Piton samples share a similarity with the Layou Ignimbrite as the position of the most sodic peak is also $\sim \mathrm{An}_{54}$. 

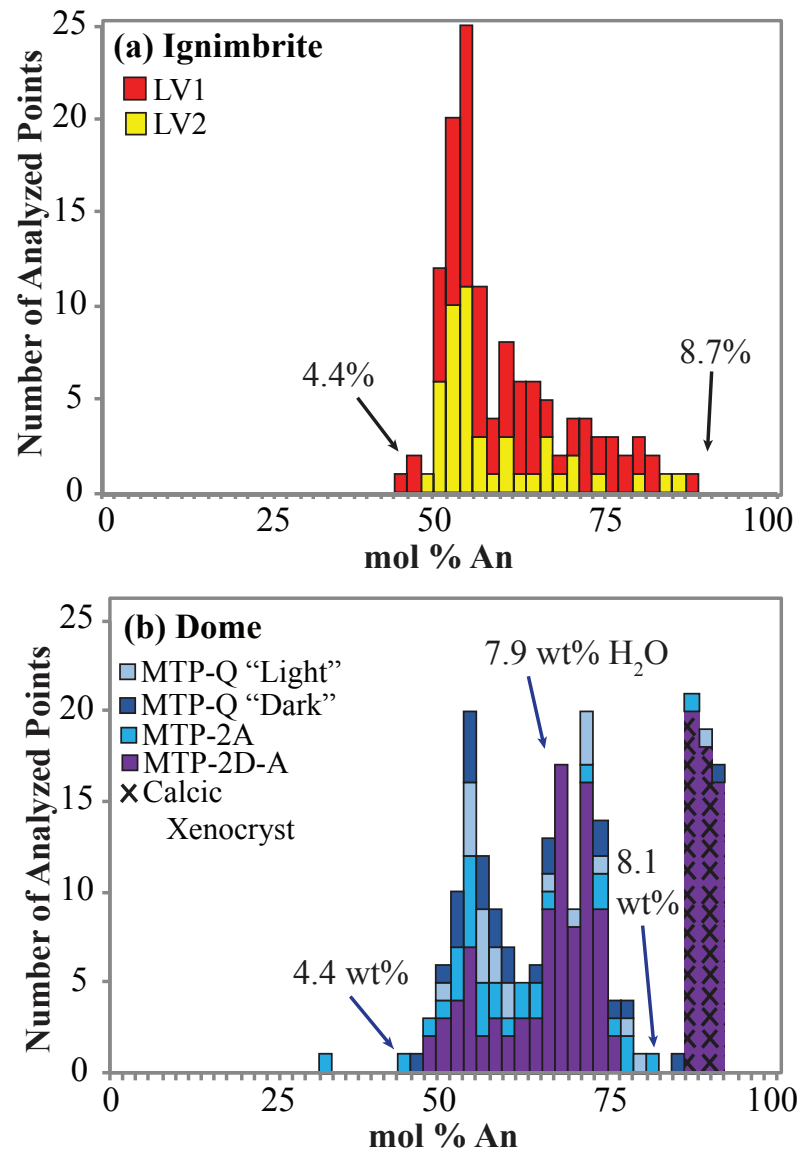

Figure 1: Plagioclase compositions for the (a) Layou Ignimbrite and the and the (b) Morne Trois Piton Lava dome are shown as histograms as a function of mol\% An (see text for detailed discussion)

\section{Calculation of Intensive Variables}

Pre-eruptive temperatures were calculated by incorporating the compositions of ilmenite and magnetite (Table 2) into the model of Ghiorso \& Evans (2008). Oxide pairs from two pumice samples from the Layou Ignimbrite revealed tightly constrained pre-eruptive temperatures of $769 \pm 12^{\circ} \mathrm{C}$ and $794 \pm 7^{\circ} \mathrm{C}$ (Table 2). Oxide pairs from the Morne Trois Piton samples returned a minimum pre-eruption temperature of $798 \pm 40^{\circ} \mathrm{C}$ and maximum temperature of $834 \pm 15^{\circ} \mathrm{C}$ (Fig. 2). Oxygen fugacities (relative to the $\Delta \mathrm{NNO}$ buffer) for the samples range between $\sim 0$ and +1 , which is consistent with an arc setting. Water contents in equilibrium with the melt at the time plagioclase crystallized in the ignimbrite and the dome are estimated using the plagioclase-liquid hygrometer of Waters \& Lange (2015). The pre-eruptive temperatures, calcic plagioclase compositions and whole rock compositions are incorporated in the hygrometer to calculate the maximum water contents. Temperatures, the most sodic plagioclase compositions and the interstitial melt compositions are used to estimate the minimum water contents at the time of plagioclase crystallization. Water contents in equilibrium with the melt at the time of plagioclase crystallization for the Layou Ignimbrite range from $\sim 8.4 \mathrm{wt} \%$ to $4.4 \mathrm{wt} \% \mathrm{H}_{2} \mathrm{O}$.

Water contents in equilibrium with the melt at the time of plagioclase crystallization for the Morne Trois Piton Dome are calculating using only those compositions that are probable phenocrysts (compositions of $\sim \mathrm{An}_{90}$ are excluded) and return in a range of $\mathrm{H}_{2} \mathrm{O}$ contents from 8.1 to $4.4 \mathrm{wt} \%$.

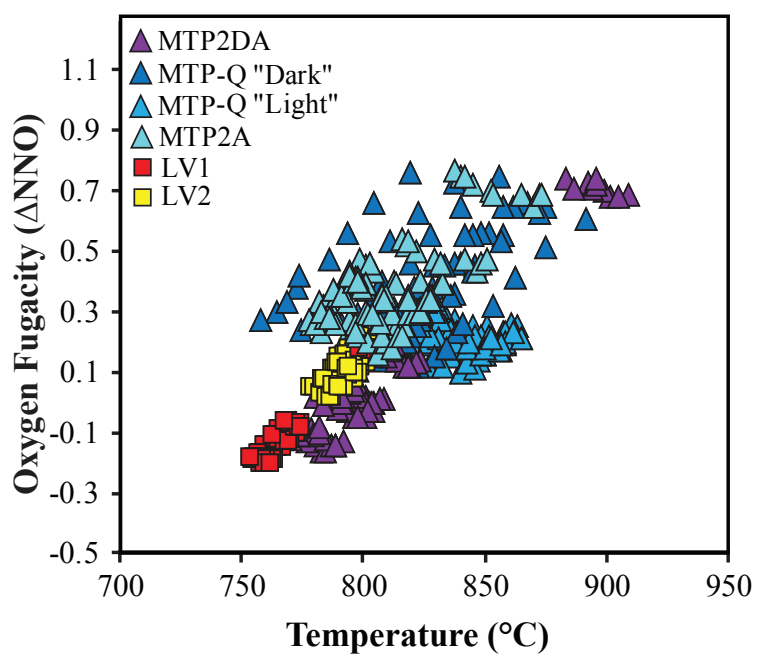

Figure 2: Pre-eruptive temperatures and oxygen fugacities are shown for lava dome samples (triangles, cool colors) and ignimbrites (squares, warm colors). Samples from the lava dome are shifted to hotter temperatures, whereas those from the pumice clasts from the ignimbrites are shifted to cooler temperatures.

\section{DISCUSSION}

An outstanding question surrounding arc volcanism is what is the mechanism that that causes a change in eruptive style. The Layou ignimbrite and the Morne Trois Piton Dome provide an opportunity to examine this question as they both erupted from the same edifice in two entirely different styles. The phenocryst assemblages and intensive variables allow us to assess possible pre-eruptive conditions that may have influenced eruptive style. Notably, one of the biggest differences between the Layou ignimbrite and the Morne Trois Piton Dome are the degree of crystallinity and 
the pre-eruptive temperatures. The Morne Trois Piton Dome is twice as crystalline as the Layou ignimbrite, which is consistent with an effusive eruptive style (e.g., if the eruption is slower there could be more time to crystallize). A surprising observation is that the Morne Trois Piton dome erupted after the Layou Ignimbrite, and has a hotter temperature.

The temperatures and the phase assemblage are evaluated using a phase diagram from the literature based on experiments from Holtz et al. (2005) conducted on a melt with a composition similar to the Layou Ignimbrite and the Morne Trois Piton Dome (Fig. 3). Each sample is shown on the diagram as an arrow plotted at its pre-eruptive temperature (a slight angle is shown to reflect the adiabatic cooling that occurs during ascent). The water contents derived from the hygrometer that correspond to the most calcic and most sodic plagioclase composition are also shown (as boxes) for each sample at its pre-eruptive temperature. The water contents recorded by plagioclase compositions show changing melt $\mathrm{H}_{2} \mathrm{O}$ contents (and or temperature; Waters \& Lange, 2015), and the ignimbrites are colder and more hydrous than the domes. The diagram suggests that the ignimbrites were sourced from deeper in the crust than the domes. This model however is problematic, as the ignimbrite erupted before the dome and is also colder than the dome; some mechanism to induce heating is required if they are from the same source.

The domes notably contain mafic enclaves, which are largely absent in the ignimbrites and could be the mechanism delivering heat into the magmatic source, mobilizing the magma. The enclaves in the Morne Trois Piton dome, studied by Howe et al. (2015), have compositions that broadly correspond to basaltic andesite and are saturated in plagioclase + clinopyroxene + orthopyroxene + magnetite + hornblende. Application of the two pyroxene thermometer of Putirka (2008) to clinopyroxene and orthopyroxene crystals in Morne Trois Piton enclaves by Howe et al (2015) reveals that the enclaves record temperatures of 920$1080^{\circ} \mathrm{C}$, demonstrating that they could be the source of the heat that shifted the dome temperatures upward. The volcanism at Morne Trois Piton broadly follows and informs the caldera cycle defined by Smith \& Bailey (1968), which initially begins with small dome

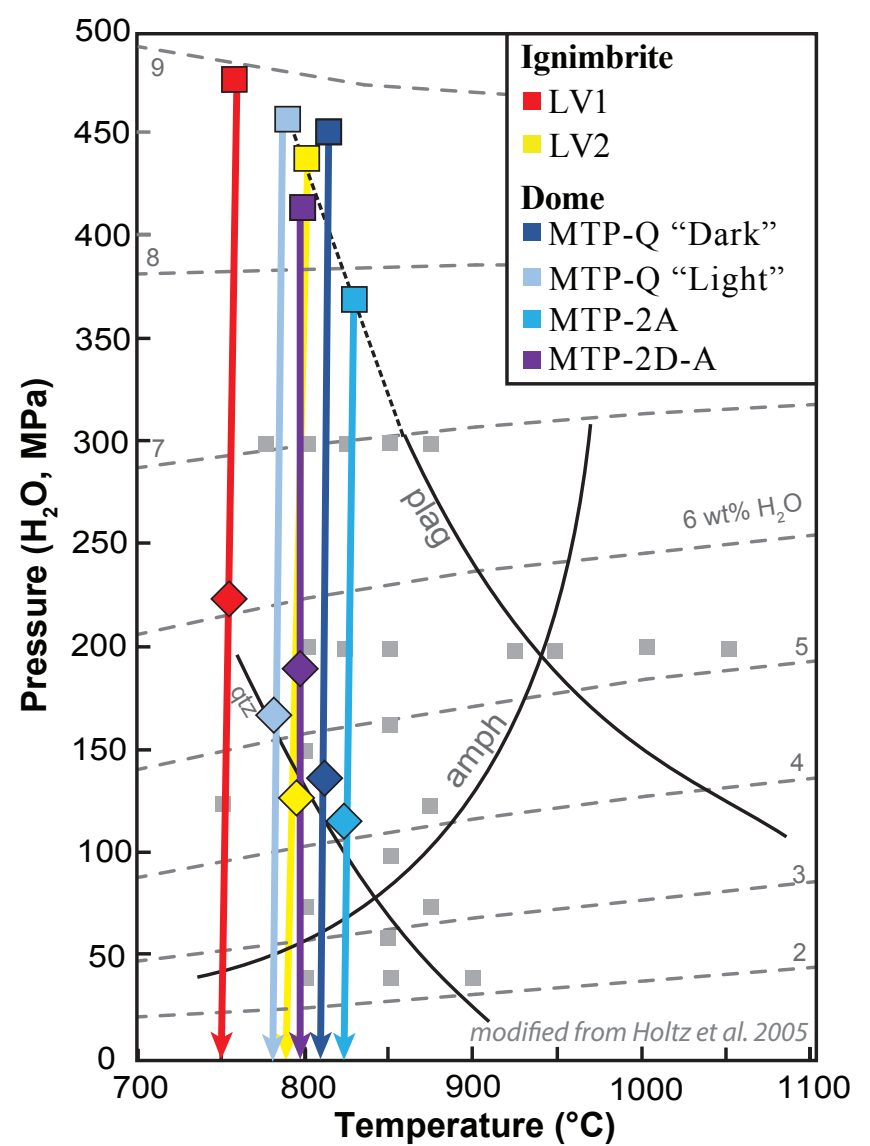

Figure 3: The samples from the Layou Ignimbrite and the Morne Trois Piton Lava dome are plotted at their pre-eruptive temperatures (Table 2) on a phase diagram from Holtz et al. (2005). Experiments that are used to define the phase boundaries are shown as grey squares, also shown are isopleths of dissolved $\mathrm{H}_{2} \mathrm{O}$ that correspond to temperatures and and pressure on the diagram for an andesite liquid calculated using Zhang et al. (2007). The maximum water contents (corresponding to the most calcic plagioclase composition) are shown as squares. The minimum water contents (corresponding to the most sodic plagioclase compositions) are shown as diamonds (see text for discussion).

forming eruptions, followed by fumarolic activity, and then they systems enters caldera collapse and an explosive phase; the pattern in volcanism then repeats. The caldera cycle broadly applies to the eruption of the Layou ignimbrite, followed by the formation of the Micotrin dome. The samples suggest that, for Dominica, the explosive phase is shifted to colder temperatures, where explosion is driven by fluid saturation (as indicated by the presence of highly vesiculated pumices), and the hotter, lava dome forming phase, where extrusion is driven by an influx of heat to the source (as indicated temperatures of enclaves; Howe et al. 2015). 


\section{CONCLUSION}

The Layou ignimbrite and the Morne Trois Piton lava dome represent different phases of the caldera cycle for Dominica. With respect to these two deposits, the Layou ignimbrite erupted at cold temperatures and high water contents, which is consistent with its general, vesiculated morphology. The Morne Trois Piton lava dome erupted later at hotter pre-eruptive temperatures and lower total water contents. This suggests both a shallowing and a heating of the source. The likely source of the influx heat that mobilized the magma to for Morne Trois Piton are the abundant mafic enclaves, which contain a phenocryst assemblage that records elevated $\left(>1000^{\circ} \mathrm{C}\right)$ temperatures. These results, combined with those from Wotten Waven caldera, suggests that the caldera cycle, as it applies to Domincia, consists of cold-explosive volcanism, followed by hot, effusive volcanism mobilized by a mafic injection (i.e., enclaves).

\section{ACKNOWLEDGEMENTS}

This material is based upon work supported by the Keck Geology Consortium and the National Science Foundation under Grant no. 1659322. I'd like to express my immense gratitude to Laura Waters and Holli Frey. This research would not have been possible without the generous support of the Keck Geology Consortium and Union College.

\section{REFERENCES}

Ghiorso, M.S. and Evans, B.W., 2008, Thermodynamics of Rhombohedral Oxide Solid Solutions and a Revision of the Fe-Ti Twooxide Geothermometer and Oxygen-barometer: American Journal of Science, v. 208, p. 957 1039.

Grove, T.L., Elkins-Tanton, L.T., Parman, S.W., Chatterjee, N., Müntener, O., and Gaetani, G.A., 2003, Fractional crystallization and mantlemelting controls on calc-alkaline differentiation trends: Contributions to Mineralogy and Petrology, v. 145, doi: 10.1007/s00410-0030448-z.

Howe, T.M., Lindsay, J.M., and Shane, P., 2015, Evolution of young andesitic-dacitic magmatic systems beneath Dominica, Lesser Antilles:
Journal of Volcanology and Geothermal Research, v. 298. 69-88.

Lindsay, J.M., Smith, A.L., Roobol, M.J., and Stasiuk, M.V., 2005, Volcanic Hazard Atlas of the Lesser Antilles: Dominica: West Indies, Seismic Research Centre, $279 \mathrm{p}$.

Putirka, K.D., 2008, Thermometers and barometers for volcanic systems, in: Putirka, K. D., and Tepley, F. eds., Reviews in Mineralogy and Geochemistry vol. 69, p 61-120

Smith, R.L. \& Bailey, R.A., 1968, Resurgent cauldrons, in Coats, R.R., Hay, R.L., and Anderson, C.A., eds., Studies in Volcanology: Geological Society of America Memoir, v. 116, p. 613-662.

Smith, A.L., Roobol, M.J., Mattioli, G.S. Fryxell, J.E., Daly, G.E., and Fernandez, L.A., 2013, The Volcanic Geology of the Mid-Arc Island of Dominica, Lesser Antilles: The Surface Expression of an Island-Arc Batholith: Boulder, Colorado, Geological Society of America Special Paper 496, $249 \mathrm{p}$.

Waters, L.E., and Lange, R.A., 2015, An updated calibration of the plagioclase-liquid hygrometerthermometer applicable to basalts through rhyolites. American Mineralogist, 100: 2172 2184.

Zhang, Y., Xu, Z., Zhu, M., and Wang, H., 2007, Silicate melt properties and volcanic eruptions. Reviews of Geophysics 45, RG4004 